\title{
Vulnerability index and capacity spectrum based methods for urban seismic risk evaluation. A comparison
}

\author{
Nieves Lantada $\cdot$ Luis G. Pujades · Alex H. Barbat
}

Received: 6 July 2007/ Accepted: 26 December 2007/Published online: 11 March 2008

(C) Springer Science+Business Media B.V. 2008

\begin{abstract}
This article contributes to the development and application of two latestgeneration methods of seismic risk analysis in urban areas. The first method, namely vulnerability index method (VIM), considers five non-null damage states, defines the action in terms of macroseismic intensity and the seismic quality of the building by means of a vulnerability index. The estimated damage degree is measured by semi-empirical functions. The second method, namely capacity spectrum based method (CSBM), considers four no damage states, defines the seismic action in terms of response spectra and the building vulnerability by means of its capacity spectrum. In order to apply both methods to Barcelona (Spain) and compare the results, a deterministic and a probabilistic hazard scenario with soil effects are used. The deterministic one corresponds to a historic earthquake, while the probabilistic seismic ground motion has a probability of exceedence of $10 \%$ in 50 years. Detailed information on the building design has been obtained along years by collecting, arranging, improving, and completing the database of the dwellings of the city. A Geographic Information System (GIS) has been customized allowing storing, analysing, and displaying this large amount of spatial and tabular data of dwellings. The obtained results are highly consistent with the historical and modern evolution of the populated area and show the validity and strength of both methods. Although Barcelona has a low to moderate seismic hazard, its expected seismic risk is significant because of the high vulnerability of its buildings. Cities such as Barcelona, located in a low to moderate seismic hazard region, are usually not aware of the seismic risk. The detailed risk maps obtained offer a great opportunity to guide the decision making in the field of seismic risk prevention and mitigation in Barcelona, and for emergency planning in the city.
\end{abstract}

\footnotetext{
N. Lantada $(\bowtie) \cdot$ L. G. Pujades

Department of Geotechnical Engineering and Geosciences, Technical University of Catalonia, Jordi Girona 1-3, Building D2, Campus Norte UPC, 08034 Barcelona, Spain e-mail: nieves.lantada@upc.edu
}

\section{A. H. Barbat}

Department of Structural Mechanics, Technical University of Catalonia, Jordi Girona 1-3, Building C1, Campus Norte UPC, 08034 Barcelona, Spain e-mail: alex.barbat@upc.edu 
Keywords Urban seismic risk · Risk scenarios · Building vulnerability ·

Damage probability assessment $\cdot$ Loss estimation

\section{Introduction}

The exponential increase in the world's population, together with the growth of big cities, which is characterized by the inadequate occupancy of the land, contributes increasing the damage due to seismic catastrophes. The high concentration of population, buildings, infrastructures, and exposed values, turn these zones into high risk areas.

During the 20th century, more than 1,100 strong earthquakes have occurred, causing more than 1,500,000 casualties. Most of them are due to buildings collapsing, which is some $90 \%$ of direct deaths. Advances in structural design were applied to new structures and, to a lesser extent, to the rehabilitation of existing structures. Nevertheless, there are many more old structures than newly constructed ones. Main and likely the only way to lessen risks in urban areas is to reduce building vulnerability.

Obviously, risk analysis should be envisaged from a multidisciplinary point of view. The geological, seismological, and engineering aspects allow estimating the risk and expected physical damage. This article focuses on estimating direct seismic damage in residential buildings, but it includes also other aspects, such as the number of casualties and economic cost. Nevertheless, it not considers other social, organizational and insti-
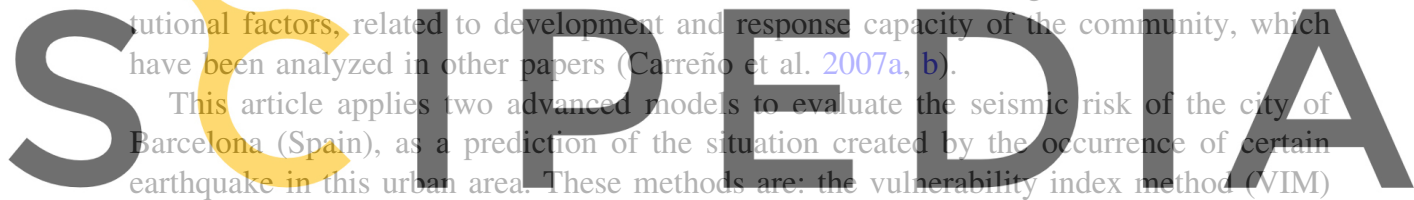

and the capacity spectrum based method (CSBM). The city is located in an area of low to

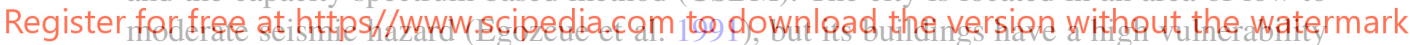

(Barbat et al. 1998) and, consequently, a significant probability of being damaged is expected even in the case of a not excessively severe earthquake. The objectives of this article are the management of the information related to seismic risk assessment with GIS tools and the conceptual comparison between the two risk evaluation approaches which have been used. The results obtained for Barcelona with both procedures are also compared.

\section{The studied urban area}

\subsection{The city}

Barcelona is the political and economical capital of Catalonia and the second city of Spain after Madrid. It is situated on the northeast coast of Spain, and Collserola mountain range and Besós and Llobregat Rivers delimit it. It has an area of about $100 \mathrm{~km}^{2}$ and it concentrates a high percentage of the total population of the region (about 1.568 million inhabitants) and an average density of 15,176 inhabitants per $\mathrm{km}^{2}$.

Barcelona is organized into 10 districts. Each district is subdivided into neighborhoods, with a total number of 38 , and each neighborhood contains the so called census zones or "zones de recerca petites" (ZRP), which are used for administrative purposes and are the 


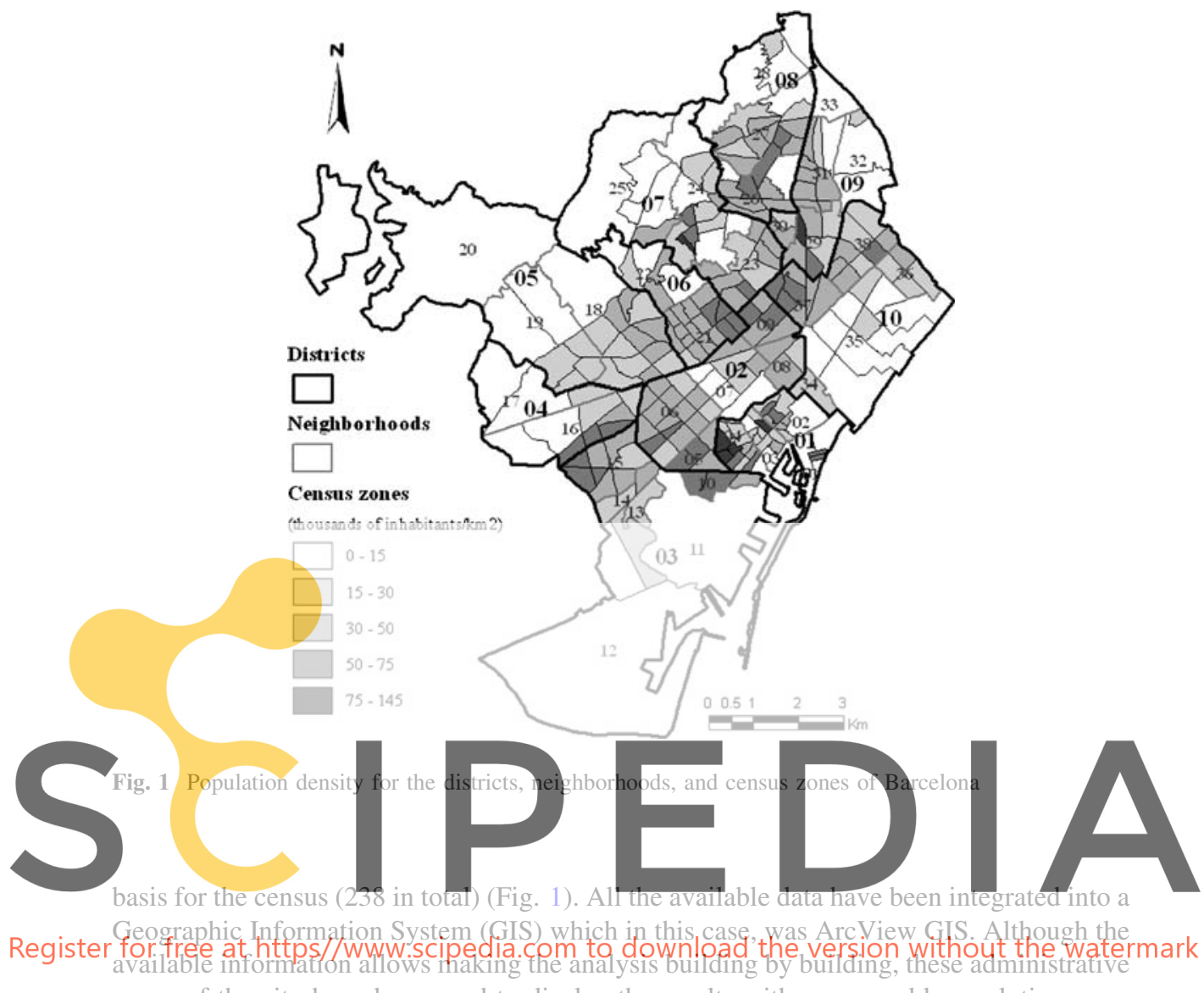

zones of the city have been used to display the results with a reasonable resolution.

With more than 2,000 years of history, Barcelona has grown from a little roman city and a walled medieval city. The districts of Ciutat Vella and Eixample are the oldest of the city and they show the greatest expected vulnerability and damage. Ciutat Vella means Old City and is the downtown of Barcelona, with the oldest buildings, mainly made of unreinforced masonry. In the 19th century the city wall was destructed. After this, the Eixample district, which means widening, was built. This district includes the urban area designed in order to organize the growth of the city between Ciutat Vella and the neighboring small towns or villages, which gave the name to the other eight districts. The Eixample district has the maximum average density and some census zones reach a density of 75,000 inhabitants per $\mathrm{km}^{2}$ (Fig. 1).

\subsection{Seismic hazard}

Barcelona has low to moderate hazard and weak tectonic motions. The hazard has been recently revaluated by the Geological Institute of Catalonia (IGC). The seismic action of the city is defined in this article by using the EMS'98 macroseismic intensities (Grünthal 1998) and by means of elastic response acceleration spectra compatible with the Eurocode 8 (CEN 2004), from both a deterministic and a probabilistic point of view. 
A seismic microzonation for the city of Barcelona based on the simulation of local effects, was also performed by Cid et al. (2001) (Fig. 2a). The four classified zones roughly correspond to the main geological units of the soils of the city. Zone R corresponds to rock outcrops (Palaeozoic and Tertiary); Zone I to Holocene deposits from the Llobregat and Besós Deltas; Zone II to Pleistocene formations with a Tertiary base and Zone III to Pleistocene outcrops without the Tertiary basis, with sufficient thickness to have an influence on the soil amplification. Each zone is characterized by an average transfer function and by an amplification factor for spectral response spectra.

The effects on the seismic action in terms of macroseismic intensities were taken into account by increasing the estimated intensity in the rock outcrops to half a unit in soil Zones II and III and to a unit in Zone I (Fig. 2a). Figure 2b shows the seismic zonation
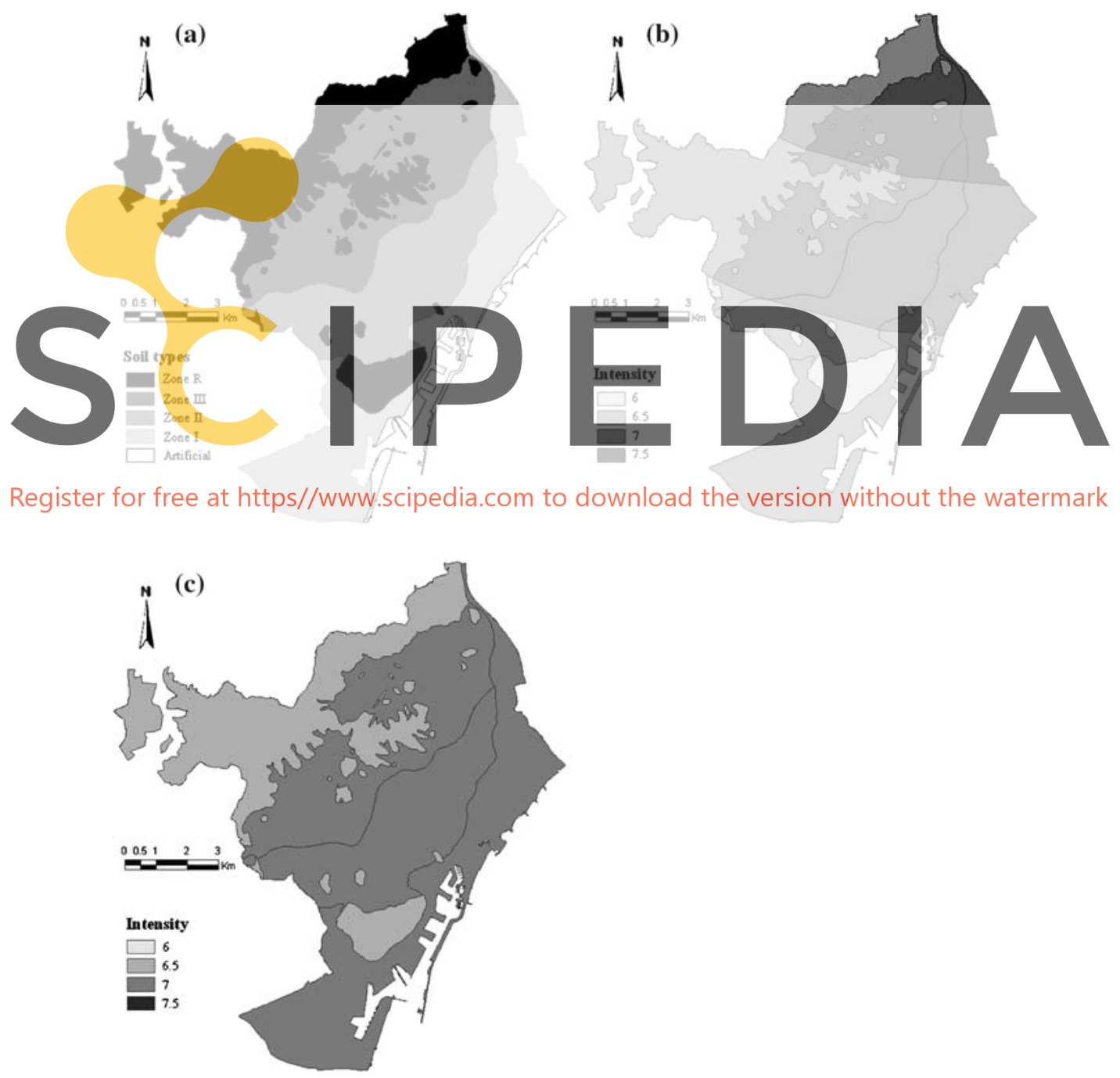

Register for free at https//www.scipedia.com to download the version without the watermark

Fig. 2 (a) Seismic microzonation based on local effects (Cid et al. 2001). (b) Deterministic scenario in macroseismic terms with soil effects. (c) Probabilistic scenario in macroseismic terms with soil effects 
map of the city soils based on the historic earthquake occurred in 1448 in Cardedeu (local magnitude of 5.5), $25 \mathrm{~km}$ away from Barcelona and with a focal depth of $7 \mathrm{~km}$ (Irizarry 2004; Olivera et al. 2006). The effect of seismic attenuation is observed towards south and the soil effects amplify the signal towards east, in the sea front. The intensities vary in Barcelona from VI, in the rock outcrops of Montjuï, to VIII, northeast of the city, closer to the epicentre with soft soils.

The probabilistic scenario corresponds to a ground motion with a $10 \%$ probability in 50 years, equivalent to an earthquake with an intensity of VI-VII MSK in the rock outcrops (Secanell et al. 2004). Intensities vary from VII in Zone R to VIII in deltaic and coastal soft soils. Figure 2c shows this probabilistic hazard scenario in terms of intensity taking into account the soil effects on the sismotectonic zonation (Cid et al. 2001).

Deterministic and probabilistic hazard scenarios were calculated by Irizarry (2004) in terms of $5 \%$ damping elastic response spectra, which constitute the departure point to estimate demand spectra and performance points. The attenuation law of Ambraseys et al. (1996) was used for spectral acceleration values. The peak ground acceleration (PGA) corresponding to the deterministic and probabilistic scenarios with a $10 \%$ probability in 50 years are mapped in Fig. 3a and b, respectively. Site effects are included both in the probabilistic and deterministic seismic hazard assessment by means of spectral amplification factors (Cid et al. 2001).
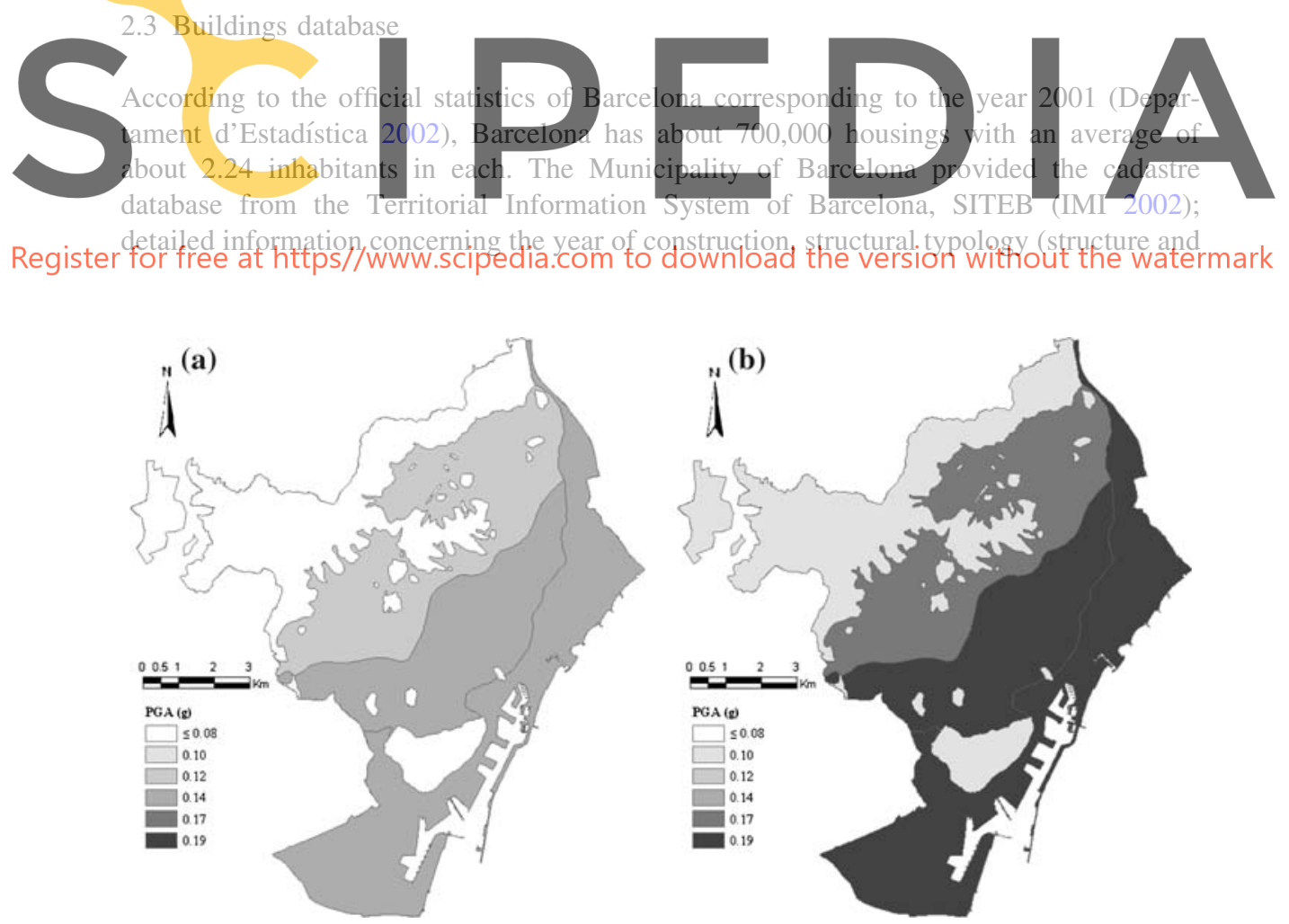

Fig. 3 Seismic hazard scenario in terms of peak ground acceleration with soil effects: (a) deterministic case and (b) probabilistic case 
slabs), and state of preservation of the buildings was completed by a detailed field work delegated by the Municipality of the city. SITEB files contain the most important data, namely the cadastre information. The total number of cadastre units or lots in these files is 80,587 and they may contain a building or may be empty. This information was used to obtain, through the GIS tool, the geometric information (horizontal and vertical configuration), the number of floors of each built lot and the length of façade. Position of individual buildings in the aggregate and the height of adjacent buildings are also obtained from the cadastre database. Other detailed information on the design and construction of the buildings of Barcelona has been obtained along years by collecting, arranging, improving, and completing the database of the housings and buildings of the city.

The collected data allowed completely characterizing geometrical features and geographical location together with the type, year of construction, and state of preservation of about 70,905 buildings (about the $85 \%$ of the total number of cadastre units). About 70,157 of them correspond to residential buildings, which represent the $92.4 \%$ of the total number of residential buildings, according to the official statistic of the city in 2001. For the others, or there is a lack of information or in the most of the cases there are not residential buildings. These special buildings have been segregated from the study.

The most representative type of buildings of the central part of Barcelona is the unreinforced masonry one, whose large number greatly influences on the overall seismic vulnerability of the city. Only a part of the structures in this area are reinforced concrete buildings with waffle slabs, which have substituted demolished unreinforced masonry buildings, but they are found in a significant number in other more recently built districts of he city. The reinforc within the high vulne elatively low seismic d conc
ability
intensi
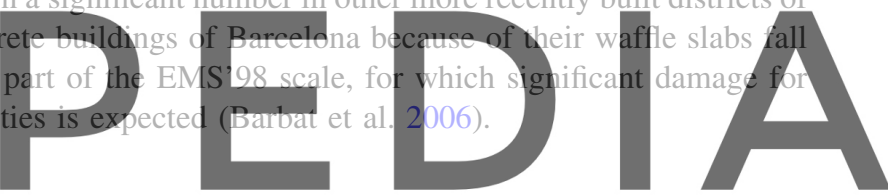

3 Physical seismic risk scenarios

Register for free at https//Www.scipedia.com to download the version without the watermark

This section is devoted to the evaluation of seismic damage of current buildings. All the collected data, vulnerability indexes, and damage factors have been used to build up an ArcView GIS application, in order to obtain detailed scenarios for each area or district and for any seismic intensity.

Traditionally, the methodologies used in Italy by Gruppo Nazionale per la Defesa dai Terremoti (GNDT 1994; Bernardini 2000) identify the existing building typologies within an area and define their class of vulnerability (i.e., A, B, C) (Giovinazzi and Lagomarsino 2002). For each vulnerability class, the relationship between intensity and damage is defined by using damage probability matrices (DPM) (Whitman 1973). Alternatively, vulnerability functions, correlating damage factor (relationship between the cost of the repair intervention and the rebuilding cost of the structure) with the PGA of the expected seismic input, can also be used to obtain the damage (Corsanego and Petrini 1994).

\subsection{Vulnerability index method (VIM)}

According to the GNDT methodology, the specific buildings of Barcelona are classified in different vulnerability classes of Risk-UE European project (Lungu et al. 2001), characterized by a similar seismic behavior (see Table 1). The basic vulnerability indexes, $V_{\mathrm{I}}$, are assigned to the most representative building typologies of the city. Their values represent 
Table 1 Building typology matrix (Giovinazzi and Lagomarsino 2002) and percentage of buildings in Barcelona

\begin{tabular}{|c|c|c|c|c|c|c|c|c|}
\hline \multirow[t]{2}{*}{$\begin{array}{l}\text { Building } \\
\text { typology }\end{array}$} & & \multirow{2}{*}{$\begin{array}{l}\text { Buildings in } \\
\text { Barcelona } \\
(\%)\end{array}$} & \multicolumn{6}{|c|}{$\begin{array}{l}\text { Vulnerability } \\
\text { classes* }\end{array}$} \\
\hline & & & A & $\mathrm{B}$ & $\mathrm{C}$ & $\mathrm{D}$ & $\mathrm{E}$ & $\mathrm{F}$ \\
\hline \multirow[t]{4}{*}{$\begin{array}{l}\text { Unreinforced } \\
\text { masonry }\end{array}$} & $\begin{array}{l}\text { M3.1: unreinforced masonry bearing walls } \\
\text { with wooden slabs }\end{array}$ & 27.5 & O & $\mathbf{\square}$ & O & & & \\
\hline & $\begin{array}{l}\text { M3.2: unreinforced masonry bearing walls } \\
\text { with Masonry vaults }\end{array}$ & 1.5 & $\bullet$ & $\mathbf{\square}$ & $\bullet$ & & & \\
\hline & $\begin{array}{l}\text { M3.3: unreinforced masonry bearing walls } \\
\text { with composite steel and masonry slabs }\end{array}$ & 27.6 & O & $\mathbf{\square}$ & $\bullet$ & & & \\
\hline & M3.4: reinforced concrete slabs & 18.8 & & $\bullet$ & $\mathbf{\square}$ & $\bigcirc$ & & \\
\hline $\begin{array}{l}\text { Reinforced } \\
\text { concrete }\end{array}$ & $\begin{array}{l}\text { RC3.2: concrete frames with unreinforced } \\
\text { masonry infill walls with irregularly } \\
\text { frames (i.e., irregular structural system, } \\
\text { irregular infills, soft/weak story) }\end{array}$ & 20.5 & & $\bullet$ & $\mathbf{\square}$ & $\mathrm{O}$ & & \\
\hline \multirow[t]{4}{*}{ Steel } & S1: steel moment frames & 1.7 & $\bigcirc$ & ○ & 口 & 0 & & \\
\hline & $\begin{array}{l}\text { S3: steel frames with unreinforced masonry } \\
\text { infill walls }\end{array}$ & & & 0 & - & ㅁ & 0 & \\
\hline & S5: steel and RC composite systems & 2.1 & & & & 0 & ש & o \\
\hline & W: wood structures & 0.3 & & 0 & - & [ & 0 & \\
\hline
\end{tabular}

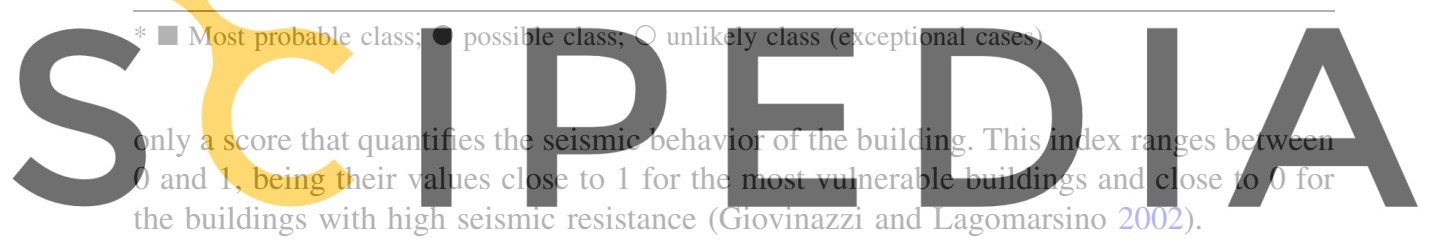

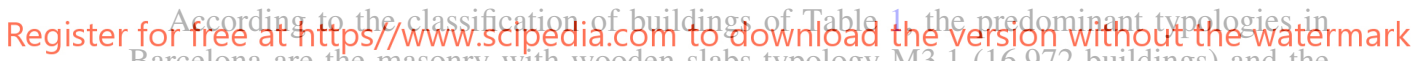
Barcelona are the masonry with wooden slabs typology M3.1 (16,972 buildings) and the masonry with composite steel and masonry slabs M3.3 (15,389 buildings).

Further refinements of the vulnerability index $V_{\mathrm{I}}$ come from behavior modifiers, which are used to evaluate a global vulnerability index of each building as follows:

$$
V_{\mathrm{I}}^{\text {building }}=V_{\mathrm{I}}^{\text {class }}+\Delta M_{\mathrm{R}}+\sum_{j=1}^{n} V m_{j}
$$

where $V_{\mathrm{I}}^{\text {class }}$ is the vulnerability index corresponding to the category of the building, $\Delta M_{\mathrm{R}}$ is a regional modifier which takes into account the peculiarities of the region or building period while $V m_{j}$ are vulnerability factors or behavior modifiers that incorporate other aspects of the building affecting its seismic behavior, and $V_{\mathrm{I}}^{\text {building }}$ is the final vulnerability index of the building (Lantada 2007). Table 2 shows the vulnerability index $V_{\mathrm{I}}^{\text {class }}$ modified with $\Delta M_{\mathrm{R}}$ based on earthquake resistant considerations and seismic codes changes in Spain. The buildings have been classified into different periods of age. It must be said that almost the $80 \%$ of the building stock of Barcelona was constructed prior to the first Spanish Seismic Code (PGS-1 1968). The average year of construction of the buildings for each district ranges from 1894 to 1956.

Two kind of behavior modifiers $V m_{j}$ are considered in Eq. 1: building modifiers and location modifiers. The building modifiers refer to the isolated building and quantify properties such as the number of floors, the length of the façade, the preservation state, 
Table 2 Vulnerability index for building typologies and periods of construction according to the Spanish seismic code level

\begin{tabular}{|c|c|c|c|c|c|c|}
\hline \multirow[t]{2}{*}{$\begin{array}{l}\text { Period of } \\
\text { construction }\end{array}$} & \multirow{2}{*}{$\begin{array}{l}\text { Spanish } \\
\text { seismic } \\
\text { code }\end{array}$} & \multirow{2}{*}{$\begin{array}{l}\text { Application } \\
\text { of code in } \\
\text { Barcelona }\end{array}$} & \multirow{2}{*}{$\begin{array}{l}\text { Lateral } \\
\text { bracing in } \\
\text { constructive } \\
\text { practice }\end{array}$} & \multirow[t]{2}{*}{$\begin{array}{l}\text { Code } \\
\text { level }\end{array}$} & \multirow[t]{2}{*}{$\begin{array}{l}\text { Buildings } \\
(\%)\end{array}$} & $\begin{array}{l}\text { Vulnerability index } \\
\left(V_{\mathrm{I}}\right)\end{array}$ \\
\hline & & & & & & $\begin{array}{lll}\text { M3.1 } & \text { M3.4 } & \text { RC3.2 } \\
\text { M3.2 } & & \end{array}$ \\
\hline
\end{tabular}

M3.3

\begin{tabular}{|c|c|c|c|c|c|c|c|c|}
\hline Before 1950 & - & - & Absent & Pre-code & 50.7 & 0.94 & - & - \\
\hline $1950-1962$ & - & - & Deficient & Pre-code & 17.3 & 0.88 & - & - \\
\hline 1963-1968 & $\begin{array}{r}\text { Recommendation } \\
\text { MV101 (1963) }\end{array}$ & $\begin{array}{l}\text { Not } \\
\quad \text { specified }\end{array}$ & Deficient & Pre-code & 10.9 & 0.81 & 0.75 & 0.75 \\
\hline 1969-1974 & $\begin{array}{l}\text { Seismic code } \\
\text { P.G.S-1 (1968) }\end{array}$ & Yes & Acceptable & Low & 9.8 & 0.75 & 0.63 & 0.63 \\
\hline 1975-1994 & $\begin{array}{l}\text { Seismic code } \\
\text { P.D.S-1 (1974) }\end{array}$ & Yes & Acceptable & Low & 11.1 & 0.69 & 0.56 & 0.50 \\
\hline $\begin{array}{l}1995 \text { until } \\
\text { now }\end{array}$ & $\begin{array}{l}\text { Seismic code } \\
\text { NCSE-94 } \\
(1994)\end{array}$ & No & Acceptable & Low & 0.2 & 0.69 & 0.56 & 0.50 \\
\hline
\end{tabular}

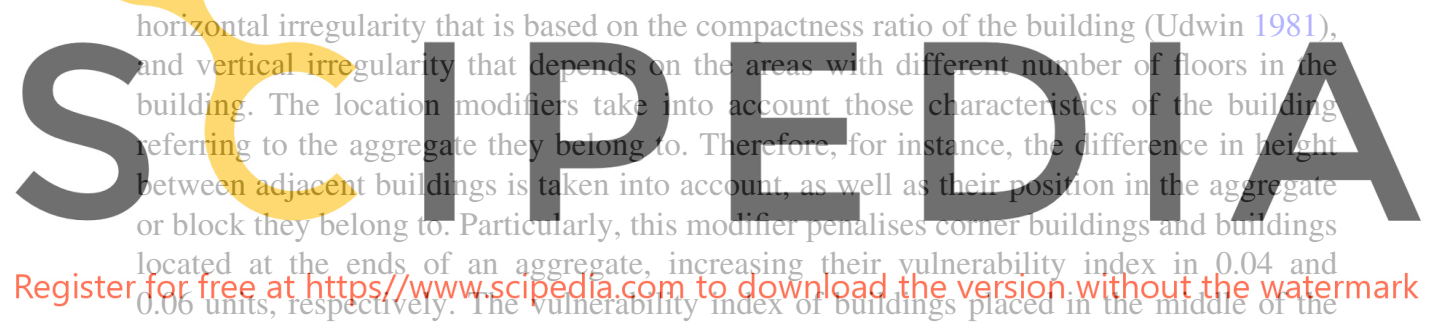

aggregates is reduced in 0.04 units. The vulnerability indexes of masonry buildings show values ranging from 0.7 to almost the unit, with a mean value of 0.87 , while indexes in reinforced concrete buildings are smaller, ranging from 0.4 to 0.85 (mean value of 0.65 ). Figure 4a shows the mean vulnerability index of masonry buildings by census zones (ZRP). A radial pattern, with the greatest vulnerability indexes, in the historic city centre is observed. It is downtown where there are many old buildings with a deficient seismic quality. Figure $4 \mathrm{~b}$ shows the distribution of the mean vulnerability indexes of the census zones for reinforced concrete buildings. A slight decrease on vulnerability can be observed but the radial pattern has disappeared. This vulnerability analysis shows the low seismic quality of the dwellings in the city, which is typical for those cities located in areas with low to moderate hazard because there is no concern for seismic-resistant protection.

Concerning the damage, the methodology recognizes a no-damage state, labelled as None and five damages states, named as Slight, Moderate, Substantial to Heavy, Very Heavy, and Destruction. A sort of mean damage grade, $\mu_{\mathrm{D}}$, permits to characterize completely the expected damage for a building, known its vulnerability and for a given intensity.

$$
\mu_{\mathrm{D}}=2.5\left[1+\tanh \left(\frac{I+6.25 \cdot V_{\mathrm{I}}-13.1}{2.3}\right)\right]
$$



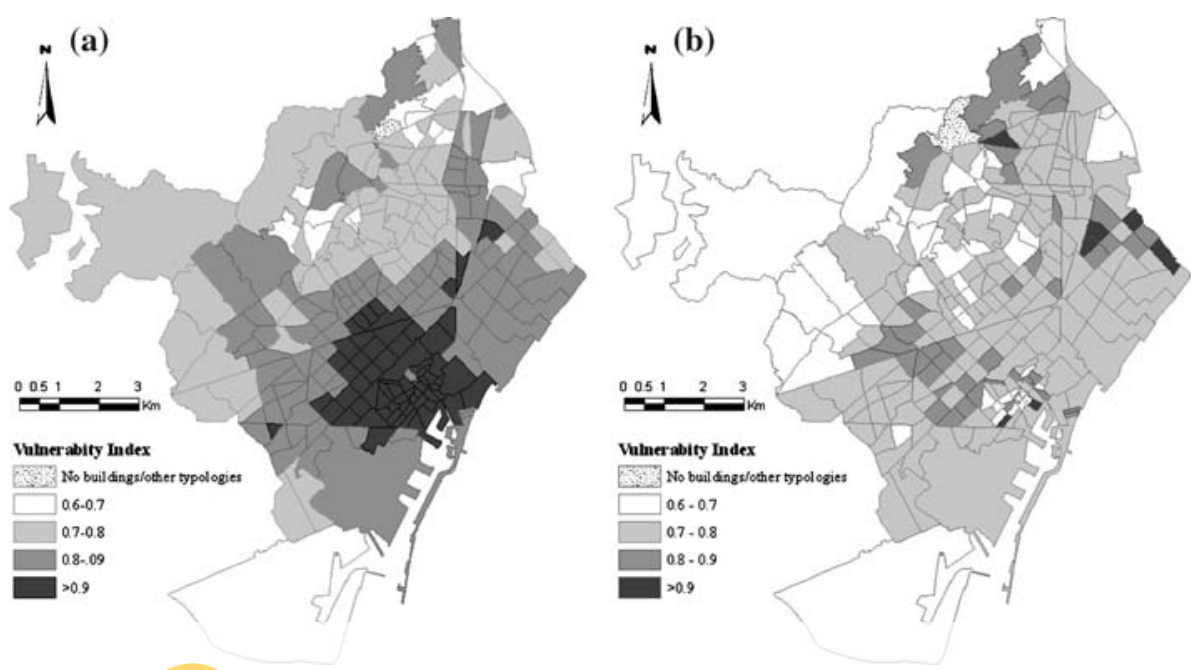

Fig. 4 Mean vulnerability indexes by census zones for (a) masonry buildings and (b) reinforced concrete buildings

Damage probability matrices, can be then easily obtained by assuming that the damage robability follows a beta probability density fin
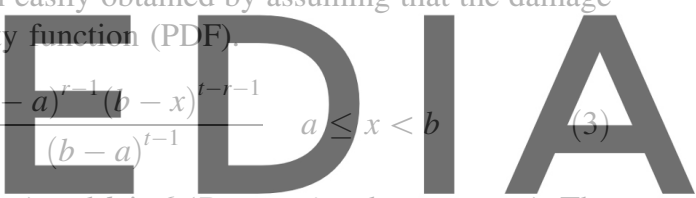

In our case $a$ is set to 0 (None damage state) and $b$ is 6 (Destruction damage state). The

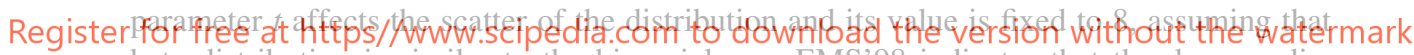
beta distribution is similar to the binomial one. EMS'98 indicates that the damage distribution of a building is binomial (Giovinazzi and Lagomarsino 2002). Finally, parameter $r$ is given as a function of $\mu_{\mathrm{D}}$ in the following equation.

$$
r=t\left(0.007 \mu_{\mathrm{D}}^{3}-0.0525 \mu_{\mathrm{D}}^{2}+0.2875 \mu_{\mathrm{D}}\right)
$$

Thus, the probability that the damage be less or equal to a damage grade $P_{\beta}(k)$ is obtained by integrating $P_{\beta}(k)$ in Eq. 3 between 0 and the $k$-damage grade. Finally, the probability of occurrence of the damage state $k, p_{k}$ is obtained as follows:

$$
p_{k}=P_{\beta}(k+1)-P_{\beta}(k)
$$

A weighted mean damage index, $D S_{\mathrm{m}}$, can be calculated by using the following equation:

$$
D S_{\mathrm{m}}=\sum_{k=0}^{5} k \cdot P\left[D S_{k}\right]
$$

where $k$ takes the values $0,1,2,3,4$, and 5 for the damage states $k$ considered in the analysis and $P\left[D S_{k}\right]$ are the corresponding probabilities. It can be considered that $D S_{\mathrm{m}}$ is close to the most likely damage state of the structure. This damage index is useful for mapping and analyzing damage distributions by using a single parameter. Of course, alternative maps may plot the spatial distribution of the probability of occurrence of a 
Table 3 Damage probability matrix for a vulnerability index of 0.4

\begin{tabular}{llllllll}
\hline Intensity & $D S_{\mathrm{m}}$ & \multicolumn{6}{l}{ Damage state probabilities } \\
\cline { 3 - 8 } & & $\begin{array}{l}\text { None } \\
(0)\end{array}$ & $\begin{array}{l}\text { Slight } \\
(1)\end{array}$ & $\begin{array}{l}\text { Moderate } \\
(2)\end{array}$ & $\begin{array}{l}\text { Substantial to heavy } \\
(3)\end{array}$ & $\begin{array}{l}\text { Very heavy } \\
(4)\end{array}$ & $\begin{array}{l}\text { Destruction } \\
(5)\end{array}$ \\
\hline VI & 0.090 & 0.9680 & 0.0282 & 0.0035 & 0.0003 & 0.0000 & 0.0000 \\
VI-VII & 0.138 & 0.9459 & 0.0473 & 0.0063 & 0.0006 & 0.0000 & 0.0000 \\
VII & 0.209 & 0.9063 & 0.0803 & 0.0121 & 0.0012 & 0.0001 & 0.0000 \\
VII-VIII & 0.316 & 0.8365 & 0.1360 & 0.0245 & 0.0029 & 0.0001 & 0.0000 \\
VIII & 0.472 & 0.7199 & 0.2212 & 0.0510 & 0.0074 & 0.0005 & 0.0000 \\
\hline
\end{tabular}

specified damage state $D S_{k}$, that is $P\left[D S_{k}\right]$. Table 3 shows an example of DPM for a vulnerability index of 0.4 .

\subsection{Capacity spectrum based method (CSBM)}

An alternative way to define damage is by using fragility curves (FEMA/NIBS 2002). For a given type of building and damage state, these curves define the probability of equalling or exceeding a considered damage state for a given seismic action. The fragility curve for a none damage state equals 1 . For no damage states, it is assumed that fragility curves follow

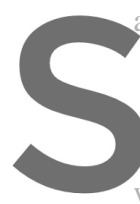
lognormal probability
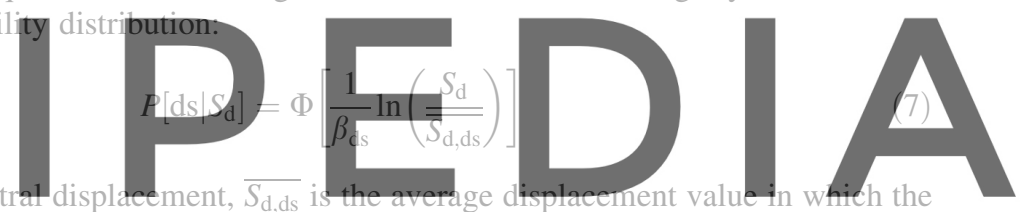

building reaches the limit of damage state $\mathrm{ds}, \beta_{\mathrm{ds}}$ is the standard deviation of the natural

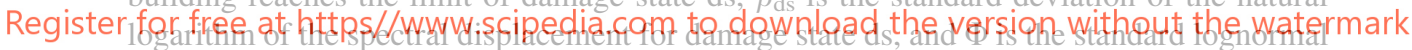

cumulative distribution function. Thus, these curves are defined by only two parameters: the average value $\overline{S_{\mathrm{d}, \mathrm{ds}}}$ which defines the point at which the probability of equalling or exceeding the damage state is $50 \%$, and the standard deviation $\beta_{\mathrm{ds}}$ that gives an idea of the dispersion.

The CSBM considers only 5 damage states: Slight, Moderate, Severe, and Complete, including the None damage state. The damage is quantified by fragility curves. A simplified way of obtaining these curves from the bilinear capacity spectra is used. The bilinear capacity spectrum is defined by means of the plastic deformation point $\left(S d_{y}, S a_{y}\right)$ and the peak capacity point $\left(S d_{u}, S a_{u}\right)$ (Barbat et al. 2006). The definition of the lognormal distribution defining the fragility curve requires estimating the average or limit value for the damage state, $\overline{S d_{i}}$, and the standard deviation, $\beta_{i}$. In this article, the simplified method suggested in project Risk-UE is followed (Milutinovic and Trendafiloski 2003). The damage state limits are defined by the relationships given in Table 4 (see also Fig. 5). In order to estimate standard deviations, the probabilities of the limit damage states are assumed to follow a binomial or a beta-equivalent distribution. Thus, by fixing the probability of exceeding the limit at $50 \%$, the probabilities for the other states can be obtained by the integral function of probability between $a$ and $x$ (Eq. 3).

Table 5 shows the values obtained. A least squares fitting of the lognormal distribution allows estimating typical deviations. Figure 6 illustrates this procedure. The points correspond to the values in Table 5, while the solid lines correspond to the fitted fragility curves. 
Table 4 Damage state thresholds according to the capacity spectrum of Fig. 5

\begin{tabular}{ll}
\hline Damage state & Damage state thresholds \\
\hline Slight & $\overline{S d_{1}}=0.7 S d y$ \\
Moderate & $\overline{S d_{2}}=S d y$ \\
Severe & $\overline{S d_{3}}=S d y+0.25(S d u-S d y)$ \\
Complete & $\overline{S d_{4}}=S d u$ \\
\hline
\end{tabular}

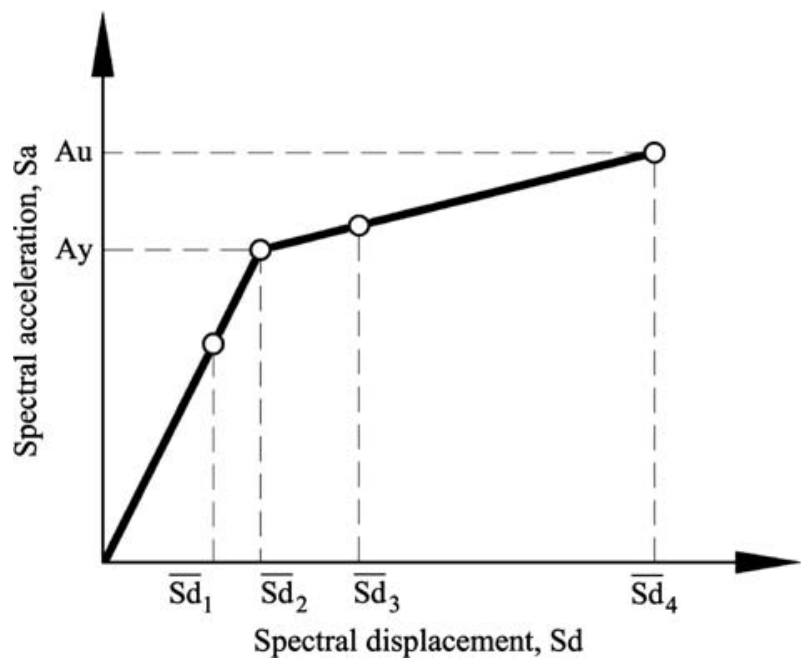

Fig. 5 Damage state thresholds defined in the bilinear capacity spectrum

Table 5 Distribution of probabilities of the expected damage states when fixing the limit of probability at $50 \%$ for each damage state

\begin{tabular}{llllll}
\hline Condition & $P_{\beta}(1)$ & $P_{\beta}(2)$ & $P_{\beta}(3)$ & $P_{\beta}(4)$ & $D S_{\mathrm{m}}$ \\
\hline$P_{\beta}(1)=50$ & 0.50 & 0.90 & 0.99 & 1.00 & 0.91 \\
$P_{\beta}(2)=50$ & 0.12 & 0.50 & 0.87 & 0.99 & 1.92 \\
$P_{\beta}(3)=50$ & 0.01 & 0.14 & 0.50 & 0.88 & 3.08 \\
$P_{\beta}(4)=50$ & 0.00 & 0.01 & 0.10 & 0.50 & 4.09 \\
\hline
\end{tabular}

The CSBM allows estimating the damage probability matrix corresponding to a given seismic scenario by obtaining the so-called performance point, which provides the expected spectral displacement caused to the building by the considered earthquake scenario, Milutinovic and Trendafiloski (2003) give three methods to determine this point (Fajfar and Gaspersic 1996; Fajfar 2002; ATC-40 1996). Figure 7 shows an example of this procedure. The non-linear behavior of the building is described by the capacity spectrum, while the seismic action is represented by the 5\% damping linear response spectrum reduced to take into account the inelastic behavior of the structure. The nonlinear response spectrum is thus obtained, also known as demand spectrum, and the performance point is determined by crossing it with the capacity spectrum. The spectral displacement corresponding to the performance point is the maximum displacement caused 
Fig. 6 Fragility curves obtained by least squares fitting to the points of Table 5
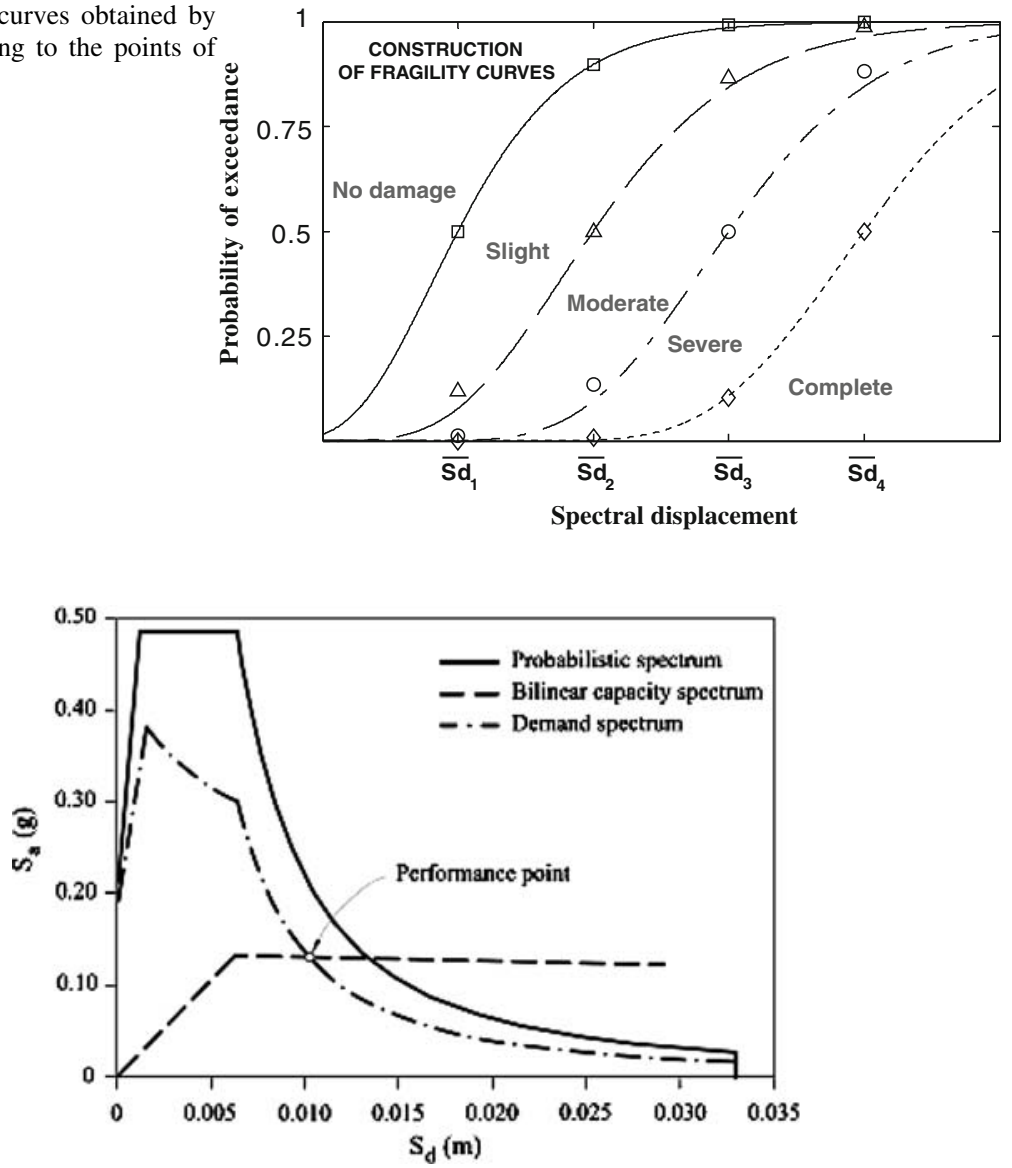

Fig. 7 Example of estimation of the performance point. The 5\% elastic demand spectrum and the inelastic response spectrum are also shown (ATC-40 1996)

in the building by the earthquake. This spectral displacement enables to determine the exceedence probabilities, by entering with this value in the fragility curves. Finally, it is possible to estimate the occurrence probability for each damage state, that is, the damage probability matrices by using the following equation:

$$
P\left[G D=D_{k} \mid i, T\right]=P\left(G D \geq D_{k} \mid i, T\right)-P\left(G D \geq D_{(k+1)} \mid i, T\right) \quad k=0 \ldots(N-1)
$$

The average damage grade or the most likely damage state can be estimated starting from these damage probability matrices by using Eq. 6 .

Bonett (2003) obtained the capacity curves and damage probability matrices for masonry buildings (type M3.3) in the city with 2, 4, and 6 floors (low-, mid-, and high-rise, respectively). Mid-rise and high-rise masonry buildings located in Zone I would suffer a damage state between 2 (moderate) and 3 (severe). This fact confirms the high vulnerability of this type of buildings. Moreno et al. (2004) and Moreno (2006) carried out an analogous study for reinforced concrete buildings (typology RC3.2) of low-rise (2 floors), mid-rise ( 5 floors), and high-rise ( 8 floors) buildings and obtained the corresponding damage probability matrices. Table 6 shows the corresponding mean damage grades to 
Table 6 Mean damage grades, $D S_{\mathrm{m}}$ for masonry and reinforced concrete buildings in Barcelona, obtained by the capacity spectrum based method for deterministic and probabilistic scenarios

\begin{tabular}{|c|c|c|c|c|c|c|c|}
\hline & \multirow[t]{2}{*}{ Zone } & \multicolumn{3}{|c|}{ Unreinforced masonry } & \multicolumn{3}{|c|}{ Reinforced concrete } \\
\hline & & $\begin{array}{l}\text { Low-rise } \\
\text { (1-2 floors) }\end{array}$ & $\begin{array}{l}\text { Mid-rise } \\
\text { (3-5 floors) }\end{array}$ & $\begin{array}{l}\text { High-rise } \\
\text { ( } \geq 6 \text { floors) }\end{array}$ & $\begin{array}{l}\text { Low-rise } \\
\text { (1-3 floors) }\end{array}$ & $\begin{array}{l}\text { Mid-rise } \\
\text { (4-7 floors) }\end{array}$ & $\begin{array}{l}\text { High-rise } \\
\text { ( } \geq 8 \text { floors) }\end{array}$ \\
\hline \multirow{4}{*}{$\begin{array}{l}\text { Deterministic } \\
\text { scenario }\end{array}$} & $\mathrm{I}$ & 0.07 & 2.34 & 2.40 & 1.96 & 1.23 & 0.82 \\
\hline & II & 0.35 & 1.60 & 1.56 & 1.33 & 0.44 & 0.30 \\
\hline & III & 0.11 & 1.25 & 1.16 & 0.89 & 0.21 & 0.10 \\
\hline & $\mathrm{R}$ & 0.00 & 0.64 & 0.57 & 0.34 & 0.11 & 0.11 \\
\hline \multirow{4}{*}{$\begin{array}{l}\text { Probabilistic } \\
\text { scenario }\end{array}$} & $\mathrm{I}$ & 0.50 & 2.81 & 2.98 & 2.05 & 1.51 & 1.19 \\
\hline & II & 1.07 & 2.31 & 2.44 & 1.61 & 0.83 & 0.68 \\
\hline & III & 0.81 & 2.01 & 2.15 & 1.30 & 0.53 & 0.44 \\
\hline & $\mathrm{R}$ & 0.03 & 1.60 & 0.50 & 0.78 & 0.44 & 0.52 \\
\hline
\end{tabular}

masonry and reinforced concrete buildings. Starting from these mean damage grades, damage probability matrices can be obtained (Barbat et al. 2008). Using these damage probability matrices, damage scenarios were built.

\subsection{Comparison of results}

Results for seismic risk scenarios simulated for Barcelona are shown in this section. Spatial convolution between seismic hazard and vulnerability index in VIM and fragility curves in CSBM, as well as damage probability matrices, allow estimating the spatial distribution of the expected damage. The details and quality of the building's database of Barcelona allowed performing a vulnerability and damage analysis building by building. Therefore, the used GIS tool allows obtaining detailed maps for any district, neighborhood or administrative division at a building level.

In order to compare the results obtained with both methods, a graduated grey scale has been adopted to represent the 0-4 damage states (see Table 7). This study takes into account that the complete damage grade in CSBM includes both the very heavy and destruction damage states of VIM. The reason is that when damage is extensive, it is likely that the building be demolished, as the damage is irreparable.

The mean damage grade for the entire city with the VIM is 1.65 and 1.59 for the deterministic and the probabilistic hazard scenarios, respectively, which correspond to a

Table 7 Mean damage index values and damage states

\begin{tabular}{lll}
\hline $\begin{array}{l}\text { Mean damage } \\
\text { index intervals } \\
\left(D S_{\mathrm{m}}\right)\end{array}$ & $\begin{array}{l}\text { More probable } \\
\text { damage state } \\
\text { in VIM }\end{array}$ & $\begin{array}{l}\text { More probable } \\
\text { damage state } \\
\text { in CSBM }\end{array}$ \\
\hline $0-0.5$ & No damage & No damage \\
$0.5-1.5$ & Slight & Slight \\
$1.5-2.5$ & Moderate & Moderate \\
$2.5-3.5$ & Substantial to Heavy & Severe \\
$3.5-4.5$ & Very Heavy & Complete \\
$4.5-5.0$ & Destruction & \\
\hline
\end{tabular}


moderate damage state according to Table 7. The expected mean damage state for Ciutat Vella is 2.43 and 2.45 in the deterministic and probabilistic cases, respectively. For the CSBM, the mean damage grade is 0.86 for the deterministic hazard scenario, while for the probabilistic case is 1.51 , which, respectively, correspond to slight and moderate damage states according to Table 7. The expected mean damage states for Ciutat Vella are 1.78 and 2.51 in the deterministic and probabilistic hazard cases, respectively. Therefore, the risk scenarios obtained with the VIM are the more damaging. On the other hand, when applied the CSBM, the risk obtained for the probabilistic hazard scenario is more damaging than that obtained for the deterministic one. This fact is typical in areas with low to moderate seismic hazard, where the 475 years return period earthquake tends to be greater than the maximum historical earthquake suffered by the city.

Physical seismic risk scenarios for the deterministic and probabilistic hazard are shown for census zones in Fig. 8 for VIM and in Fig. 9 for CSBM, respectively. The scenarios of these figures provide average information easy to analyze and interpret, useful for preparedness, risk management, and emergency planning. The distribution of damage for the VIM in the deterministic hazard case of Fig. 8 follows a radial pattern from downtown to the outskirts of Barcelona. It is also possible to see in this figure a higher damage in the nearness of the epicentre of the considered earthquake (northern part of the city).

Another useful way of representing damage is by means of maps showing the occurrence probability of a certain damage state. Thus, Fig. 10a shows the moderate and severe damage state probabilities for the deterministic hazard scenario of VIM for the oldest city district (Ciutat Vella). It can be seen in Fig. 10b how the deterministic hazard scenario would produce a significant number of severely damaged buildings in the Ciutat Vella district, since almost a half of its buildings would experiment severe damage state probabilities of about $40-50 \%$.

In order to decide if using the VIM or the CSBM in the study the seismic risk of a given seismic area, it is important to take into account that both methods are adequate, but one or the other can provide better results according to the available information for the buildings.
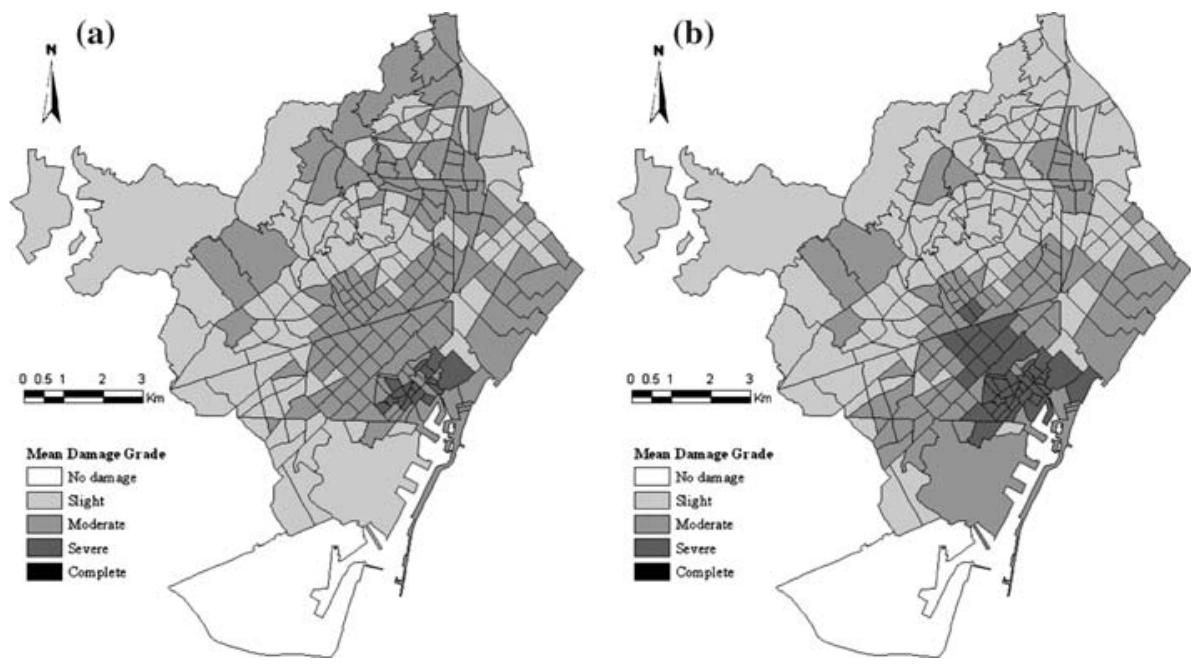

Fig. 8 Distribution of the estimated mean damage state using VIM by census zones for (a) deterministic hazard scenario and (b) probabilistic hazard scenario 

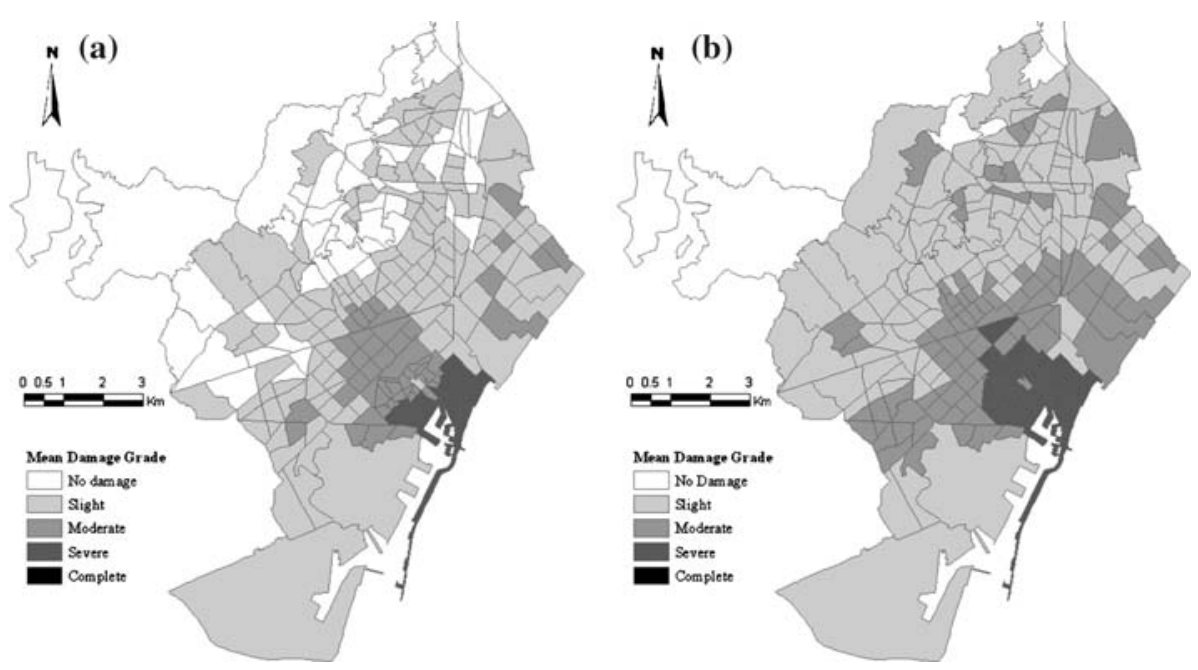

Fig. 9 Distribution of the estimated mean damage using CSBM by census zones for (a) deterministic hazard scenario and (b) probabilistic hazard scenario
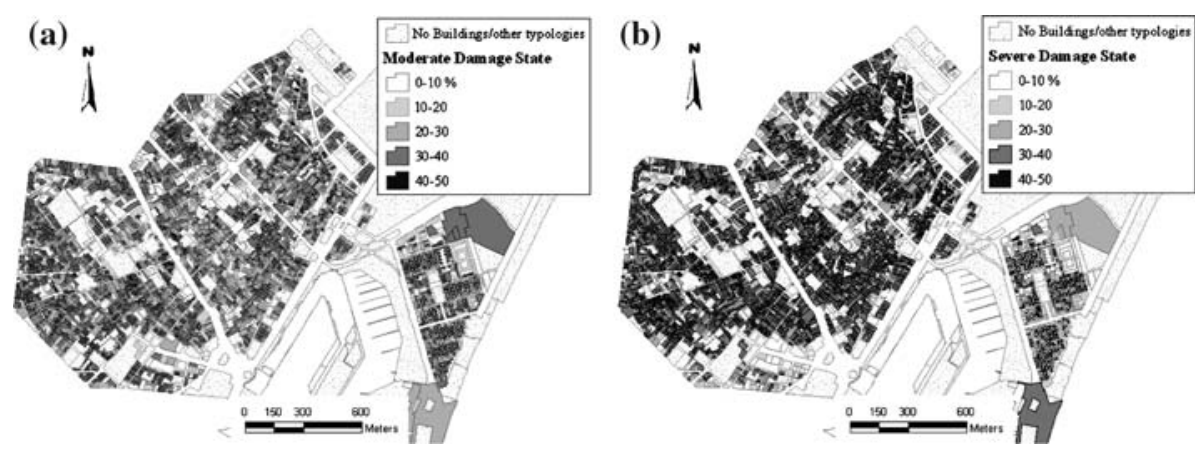

Fig. 10 Building by building damage scenario of Ciutat Vella district obtained for the deterministic hazard scenario using VIM: (a) moderate damage state and (b) severe damage state

For instance, in the case of Barcelona, the VIM provides more detailed results and thus a better insight to the seismic risk state of Barcelona. Nevertheless, in the case of a massive application to a whole urban area, both methods provide similar results, as it can be seen in Figs. 8 and 9. Anyway, when a single building has to be evaluated, the CSBM is preferable.

The direct physical damage is the starting point for other aspects of risk, such as damage to population, institutions and services, as well as to the economical and social system of the city. ATC-13 (1985), Coburn and Spence (2002) or Vacareanu et al. (2004) provide tools to incorporate to the physical risk analysis, the number of casualties and deaths, homeless population, and the economic cost, among others. These tools use empirical functions, developed starting from observed data of past earthquakes and are usually based on the knowledge of the occurrence probabilities of the physical damage states. These aspects are studied in the following two sections. 


\section{Damage to population}

Damage to population is first analyzed, considering deceased and injured people. To evaluate the expected number of deaths, the casualty model given by Coburn and Spence (2002) has been applied:

$$
K_{S}=C \cdot[M 1 \cdot M 2 \cdot M 3 \cdot(M 4+M 5 \cdot(1-M 4))]
$$

In this equation, $K_{S}$ is the number of casualties; $C$ is the number of collapsed buildings, evaluated by summing, for all building classes, the number of buildings of the class multiplied by the complete damage state or collapse probability; $M 1$ is the occupancy rate, that is, the number of inhabitants per building; $M 2$ is the occupancy at time of earthquake and a value of $80 \%$ for residential buildings at night is assumed here; $M 3$ is the percentage of occupants trapped by collapse; $M 4$ is the percentage of fatalities among the trapped persons during the earthquake and strongly depends on the building typology; finally, M5 represents the post-collapse mortality. The cases of light injured people, injuries requiring hospitalization, the life threatening cases, and the death people are considered here as different cases of casualties. Table 8 shows the adopted values of the parameters M2-M5 in Eq. 9.

Concerning $M 1$, the total number of masonry buildings is about four times greater than the number of reinforced concrete buildings. Nevertheless, the height of reinforced concrete buildings is about twice the height of that corresponding to masonry buildings. Finally, the plant area for masonry and for reinforced concrete buildings is similar, indicating the greater size of reinforced concrete buildings when compared with masonry buildings. Consequently, the number of dwellings per reinforced concrete building is higher than the number of dwellings per unreinforced masonry building. The factor $M 1$, that is the number of inhabitants per building, has been calculated for each census zone and for each type of building. The occupancy rate $M 1$ has been revaluated by assuming that

Table 8 Assumed values for the coefficients of Eq. 9 (adapted from Coburn and Spence 2002)

\begin{tabular}{|c|c|c|c|c|c|c|c|}
\hline \multirow[t]{2}{*}{ Typology } & \multirow{2}{*}{$\begin{array}{l}M 2 \\
(\%)\end{array}$} & \multirow{2}{*}{$\begin{array}{l}M 3 \\
(\%)\end{array}$} & \multicolumn{4}{|l|}{$M 4(\%)$} & \multirow{2}{*}{$\begin{array}{l}M 5 \\
(\%)\end{array}$} \\
\hline & & & $\begin{array}{l}\text { Light } \\
\text { injured }\end{array}$ & $\begin{array}{l}\text { Injuries } \\
\text { requiring } \\
\text { hospitalization }\end{array}$ & $\begin{array}{l}\text { Life } \\
\text { threatening } \\
\text { cases }\end{array}$ & Fatalities & \\
\hline Unreinforced masonry & 80 & 5 & 30 & 30 & 25 & 15 & 60 \\
\hline Reinforced concrete & 80 & 50 & 10 & 40 & 10 & 40 & 90 \\
\hline
\end{tabular}

Table 9 Summary of casualties for the deterministic and probabilistic earthquake scenario obtained by VIM and CSBM

\begin{tabular}{llllll}
\hline & $\begin{array}{l}\text { Light } \\
\text { injured }\end{array}$ & $\begin{array}{l}\text { Injuries } \\
\text { requiring } \\
\text { hospitalization }\end{array}$ & $\begin{array}{l}\text { Life } \\
\text { threatening } \\
\text { cases }\end{array}$ & $\begin{array}{l}\text { Total } \\
\text { Injuries }\end{array}$ & Fatalities \\
\hline VIM: deterministic scenario & 1,581 & 2,057 & 1,272 & 9,710 & 6,510 \\
VIM: probabilistic scenario & 1,231 & 1,710 & 1,131 & 4,072 & 5,372 \\
CSBM: deterministic scenario & 219 & 387 & 459 & 1,066 & 1,233 \\
CSBM: probabilistic scenario & 513 & 1,171 & 705 & 2,394 & 3,695 \\
\hline
\end{tabular}


reinforced concrete buildings contain more dwellings and therefore more people because of its bigger size. Attending the total floor area of masonry and reinforced concrete buildings, reasonable weights of 45 and $55 \%$ were assumed for masonry and concrete buildings, respectively.

Table 9 summarizes the total fatalities and injured people obtained for both hazard scenarios and both risk evaluation methods. Low intensity hazard leads to low values of coefficient $C$ in Eq. 9 and sparse and incomplete deaths distribution, not significant for the population and the built environment. Figures 11 and 12 show the casualty distribution by census zones evaluated with both methods for the deterministic and probabilistic hazard
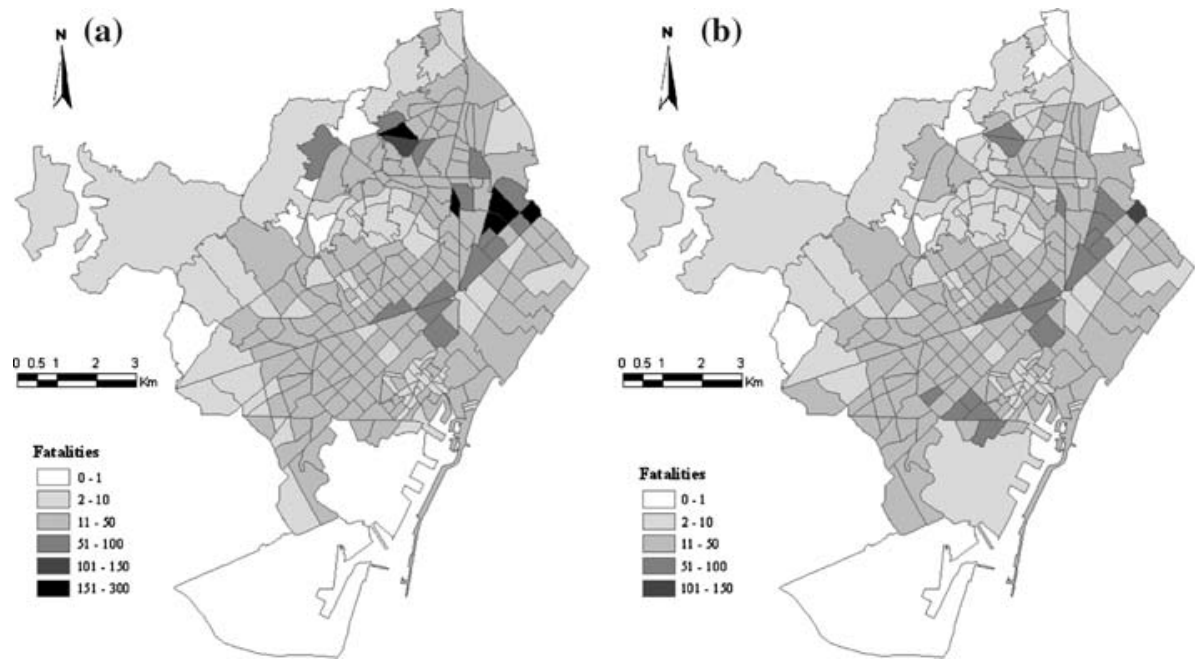

Fig. 11 Distribution of fatalities by census zones using VIM for (a) deterministic hazard scenario and (b) probabilistic hazard scenario
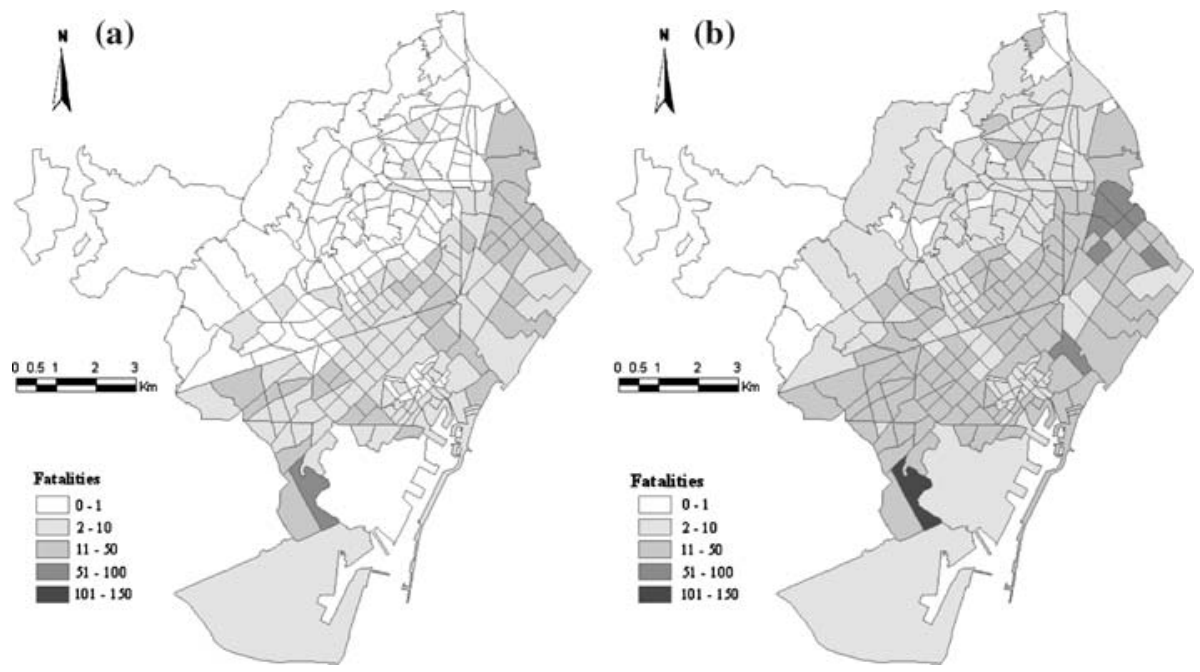

Fig. 12 Distribution of fatalities by census zones using CSBM for (a) deterministic hazard scenario and (b) probabilistic hazard scenario 
scenarios. An analogue procedure has been applied to estimate the injured people scenarios (see Figs. 13 and 14).

It can be seen in Figs. 11 and 12 that the risk calculated with the VIM for deterministic hazard scenario is more severe. The cause of most of the dead and injured people is the collapse of reinforced concrete buildings. This is mainly due to the differences between the coefficients $M 3$ and $M 4$ of Table 8, but in fact it reveals which was the actual effect of the collapse of certain types of reinforced concrete buildings during past earthquakes
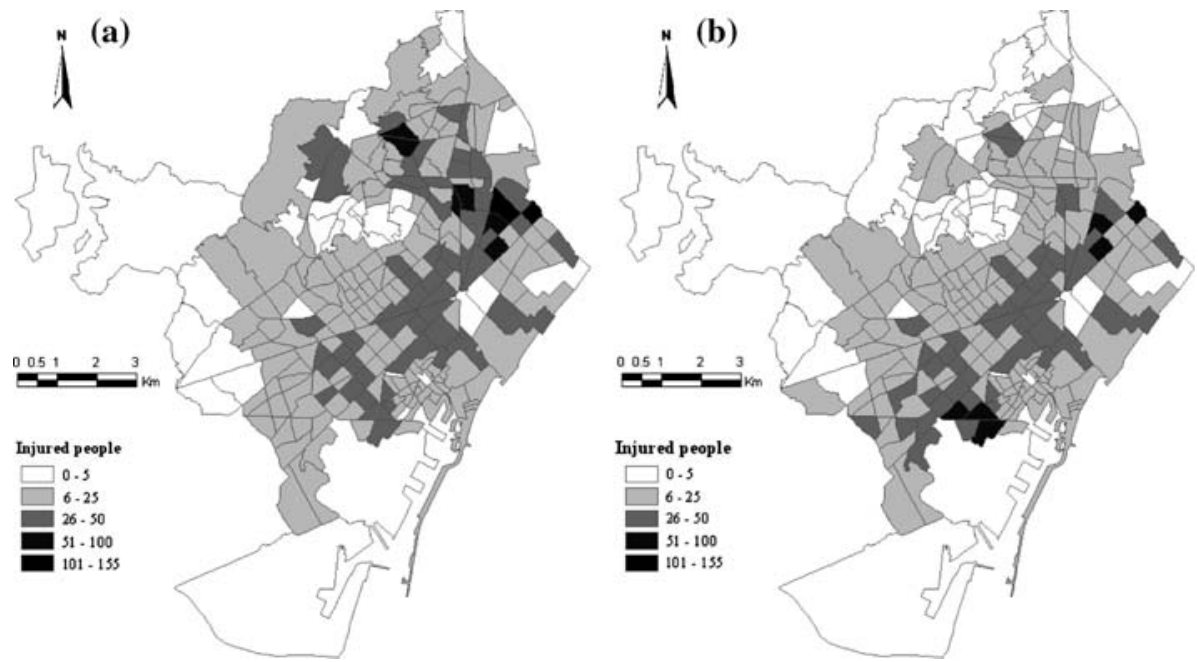

Fig. 13 Distribution of injured people by census zones using VIM for (a) deterministic hazard scenario and (b) probabilistic hazard scenario
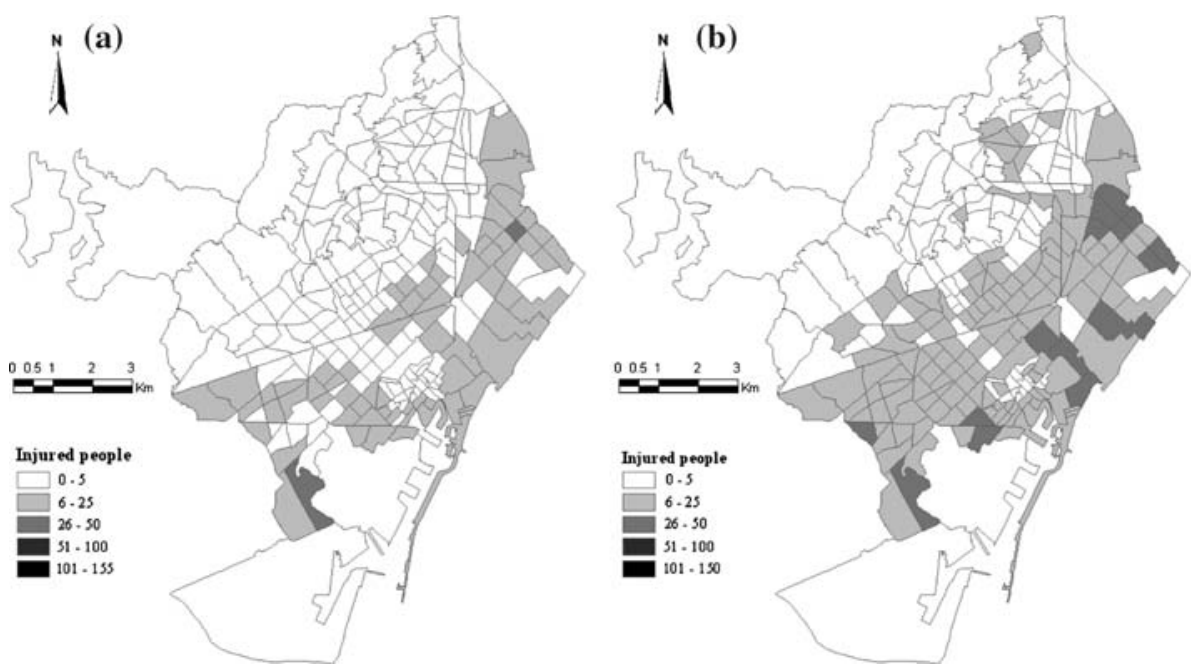

Fig. 14 Distribution of injured people by census zones using CSBM for (a) deterministic hazard scenario and (b) probabilistic hazard scenario 
(Coburn and Spence 2002). Expected casualties in an urban area are strongly correlated not only with the severity of the hazard scenario but also with the density of population and of the built area.

\section{Economic cost}

Nowadays, in Spain, construction is a very dynamic sector, in which building and dwelling prices strongly increase year by year. The housing prices in Barcelona increased in the last five years about $14 \%$ per year according to the Municipal Council of Barcelona. Based on these data, the economical losses are estimated as the present reposition cost of the damaged buildings. This value is determined by considering that reconstruction is made with reinforced concrete buildings. It has to be remarked that the construction cost does not include the cost of land.

However, the construction cost has increased considerably in the last years (about a $10 \%$ per year) and, taking into account that the final cost depends on these values, two economic cost scenarios have been evaluated in this study. The first one provides the absolute cost, in millions of Euros, while the second one gives the relative economic cost, that is, the expected equivalent floor area destroyed by the earthquake. In fact, the step from one scenario to the other can be made by simply multiplying the built square meters by the value of repairing or constructing a new square meter of building. Thus, the economic cost due to the damage caused by a seismic crisis in current buildings is given by the following equation:

$$
S_{\text {Cost }}=\sum_{k=2}^{5} C S(k)=V_{\mathrm{C}} \cdot \sum_{k=2}^{5} \sum_{j=1}^{\mathrm{Nb}}\left[\operatorname{Area}(j) \cdot P_{S}(k, j) \cdot R C(k, j)\right]
$$

where $S_{\text {Cost }}$ is the sum of the $C S(k)$ repair costs due to the damage state $k$ (damage state $1-$ none is not considered, because there is no any induced cost when there is no damage); $V_{\mathrm{C}}$ is the cost per unit area. A constant value of $V_{\mathrm{C}}$ is assumed for all building typologies; Area is the building area; $P_{S}(k, j)$ is the probability for the building $j$ to be in the damage state $k$ and $R C(k, j)$ is the repair value due to the damage state $k$ for the building $j ; R C(k, j)$ is given as a percentage of the reposition cost per square meter. A reasonable value of $V_{\mathrm{C}}$ for a residential building is $723 € / \mathrm{m}^{2}$ which corresponds to the situation of the Spanish construction market (Boletín Económico de la Construcción 2007). Table 10 shows the values for $R C(k, j)$ while column 3 of this table gives the values $R C(k, j) \cdot V_{\mathrm{C}}$, which have been assumed to be dependent on the damage state $k$ but not on the structural typology.

Table 10 Absolute repair cost per unit area for each damage state

Percentages of repair to reposition cost are also given (ATC-13 1985)

\begin{tabular}{lcc}
\hline Damage states & $\begin{array}{l}\text { Percentages } \\
(\text { ATC-13 1985) }\end{array}$ & $\begin{array}{l}\text { Absolute values } \\
\left(€ / \mathrm{m}^{2}\right)\end{array}$ \\
\hline 1-None & 0 & 0 \\
2-Slight & 2 & 15 \\
3-Moderate & 10 & 72 \\
4-Severe & 50 & 362 \\
5-Complete & 100 & 723 \\
\hline
\end{tabular}


In this case, starting from Eq. 10, a relative economic cost $R_{\text {Cost }}$ can be defined as

$$
R_{\text {Cost }}=\frac{S_{\text {Cost }}}{V_{\mathrm{C}}}=\sum_{k=2}^{5} \sum_{j=1}^{\mathrm{Nb}}\left[\operatorname{Area}(j) \cdot P_{S}(k, j) \cdot R C(k, j)\right]
$$

Additional economic losses due to the damage of residential building contents is about the $50 \%$ of the building reposition value (ATC-13 1985). This value is added to the structural cost, $S_{\text {Cost }}$, in order to obtain the total economic cost $T_{\text {Cost }}$. Table 11 summarizes the total cost $T_{\text {Cost }}$ in millions of Euros, caused by the considered deterministic and probabilistic earthquake hazard scenarios (Figs. 15 and 16). The total cost $T_{\text {Cost }}$ obtained using the VIM for the probabilistic hazard scenario would be higher than 16,000 million of Euros.

Table 11 Summary of the economic losses in Barcelona for the deterministic and probabilistic earthquake scenarios obtained by VIM and CSBM

\begin{tabular}{lclll}
\hline & $\begin{array}{l}\text { Collapsed } \\
\text { area }(\mathrm{Ha})\end{array}$ & $\begin{array}{l}\text { Structural } \\
\text { damage cost } \\
(\text { million } €)\end{array}$ & $\begin{array}{l}\text { Building } \\
\text { content losses } \\
(\text { million } € \text { ) }\end{array}$ & $\begin{array}{l}\text { Total direct } \\
\text { economic losses } \\
\text { (million } € \text { ) }\end{array}$ \\
\hline VIM: deterministic scenario & 1,466 & 10,596 & 5,298 & 15,894 \\
VIM: probabilistic scenario & 1,488 & 10,758 & 5,379 & 16,137 \\
CSBM: deterministic scenario & 574 & 4,152 & 2,076 & 6,228 \\
CSBM: probabilistic scenario & 1,256 & 9,078 & 4,539 & 13,617 \\
\hline
\end{tabular}
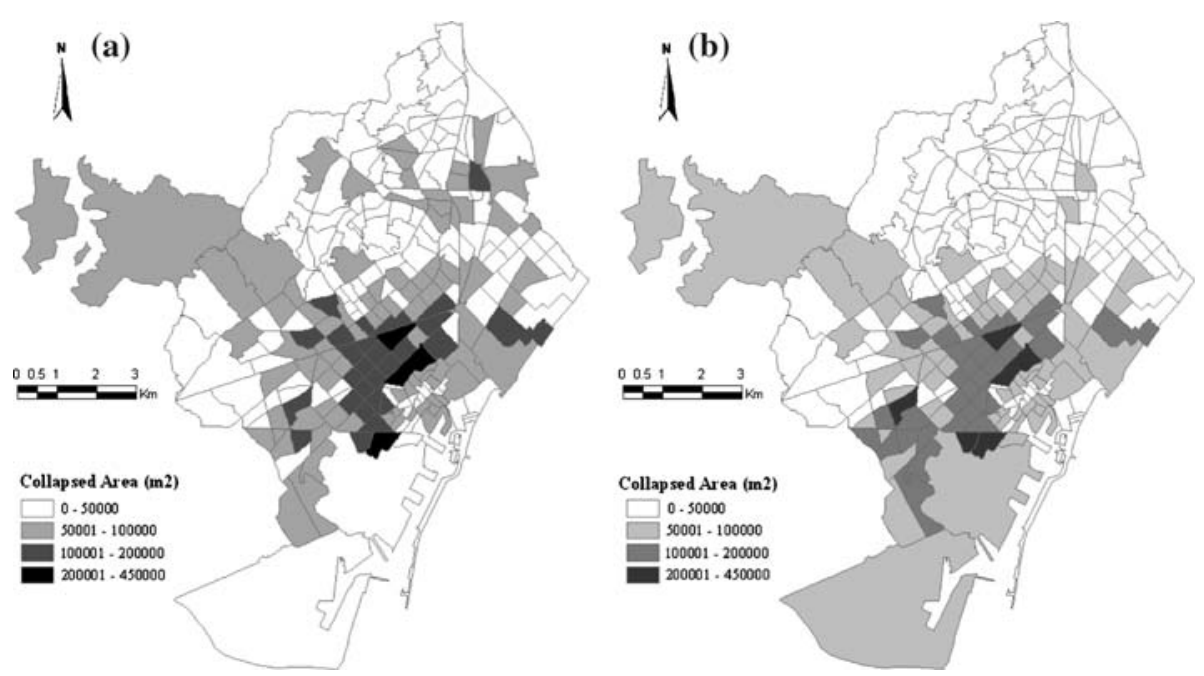

Fig. 15 Distribution of collapsed area in $\mathrm{m}^{2}$ by census zones using VIM for (a) deterministic hazard scenario and (b) probabilistic hazard scenario 

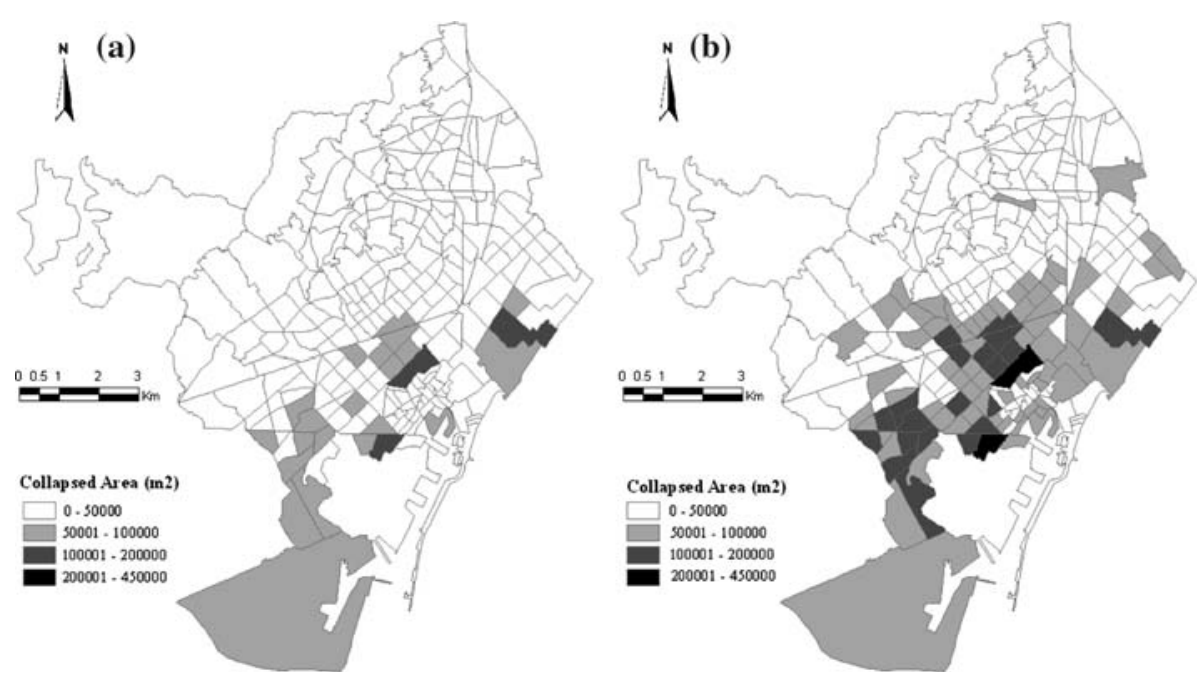

Fig. 16 Distribution of collapsed area in $\mathrm{m}^{2}$ by census zones using CSBM for (a) deterministic hazard scenario and (b) probabilistic hazard scenario

\section{Conclusions}

A GIS based tool has been developed for estimating seismic risk scenarios in urban areas. This tool incorporates two last generation methodologies for hazard, damage, and risk estimation, the VIM and CSBM. This tool is efficient in mapping average expected risk scenarios, which are required by decision makers for risk management purposes. Both methods were applied to Barcelona, a typical Mediterranean city located in a low to moderate seismic hazard region. Credible hazard scenarios have been used for the studied urban area.

The VIM is extremely versatile to characterize the seismic behavior of buildings as it allows modulating the vulnerability index representing each building, by means of regional and building modifiers. Thus, a specific class of building can cover a broader range of indexes and, thus, regarding the EMS'98 macroseismic scale, a broader range of vulnerabilities. It requires less information and allows rough simplifications of both the seismic input and the vulnerability of the buildings. The application to great urban areas is fast and simple and allows obtaining very reliable scenarios when they are interpreted from the probabilistic point of view.

The CSBM requires the analysis of the mechanical behavior of the buildings. In fact, this method could be seen as an advanced method incorporating new methodologies to analyse the damage and the seismic risk in great urban agglomeration. Despite all, this requires a greater quantity and quality of information, not only with regards to the seismic action but also to the characterization of the building's fragility. For the former, seismic acceleration data are required, while the latter requires analysing the mechanical models of buildings by means of non-linear structural analysis programs, which also implies great simplifications. It is thus a powerful method but it is expensive in terms of computing time and data quality and quantity.

To apply the CSBM, fragility curves have been developed for more than $95 \%$ of the residential building stock of the city, which is well represented by six building classes. 
Damage probability matrices have been obtained for the four seismic areas of the city, allowing developing representative risk scenarios, which are based on a complete and highly reliable database for the buildings of the city.

In spite of the differences, both methods provide excellent results, showing a reasonably good correlation with the main features of the built-up environment of the city. It is clear that in both cases a city like Barcelona, located in a low to moderate hazard region, has paid no attention to the seismic performance of its buildings, and therefore it is expected a high seismic vulnerability and a considerable risk, even for relatively small earthquakes.

Building by building seismic risk scenarios have been developed and average risk values have been calculated for the different administrative zones of Barcelona considered in the analysis. These scenarios constitute excellent information sources and tools for risk management, emergency planning and are useful for risk management and civil protection. Based on this information, the Civil Protection Service of Barcelona made proposals aiming to improve the seismic strength of the old residential buildings of the city. At the same time, it used the results of this study to design the seismic emergency plans of the city (SISMICAT 2003). The scenarios have been also used in performing the holistic evaluation of the risk in the same urban area (Carreño et al. 2007a).

The methods here described and the GIS tool developed can be easily adapted to outline risk scenarios for other cities. Probably most of the vulnerability indexes adopted for Barcelona may be slightly modified and directly used to obtain risk scenarios for other cities in Spain and, in particular, for those located in the Mediterranean region.

Acknowledgments This work has been partially sponsored by the Spanish Ministry of Education and Science and with FEDER funds (projects: CGL2004-22325-E, CGL-2005-04541-C03-02/BTE, HABITAT 2030-PSS-380000-2005-14 and SEDUREC-CSD2006-00060) and by the European Commission (RISK-UE Project -EVK4-CT-2000-00014).

\section{References}

Ambraseys NN, Simpson KA, Bommer JJ (1996) Prediction of horizontal response spectra in Europe. Earthq Eng Struct Dyn 25:375-400

ATC-13 (1985) Earthquake damage evaluation data for California, ATC-13. Applied Technology Council, Redwood City, California

ATC-40 (1996) Seismic evaluation and retrofit of concrete buildings. Applied Technology Council, Redwood City, California

Barbat AH, Mena U, Yépez F (1998) Evaluación probabilista del riesgo sísmico en zonas urbanas. Revista internacional de métodos numéricos para cálculo y diseño en ingeniería 14:247-268

Barbat AH, Pujades LG, Lantada N (2006) Performance of buildings under earthquake in Barcelona, Spain. Comput Aided Civil Infrastruct Eng 21:573-593

Barbat AH, Pujades LG, Lantada N (2008) Seismic damage evaluation in urban areas using the capacity spectrum method: Application to Barcelona. Soil Dyn Earthq Eng. doi:10.1016/j.soildyn. 2007.10.006

Bernardini A (2000) The vulnerability of buildings—evaluation on a national scale of the seismic vulnerability of ordinary building. CNR-GNDT, Rome

Boletín Económico de la Construcción (2007) Revista trimestral de precios del ramo de la construcción. Año LXVIII, trimestre 4. No. 272

Bonett RL (2003) Vulnerabilidad y riesgo sísmico de edificios. Aplicación a entornos urbanos en zonas de amenaza alta y moderada. Doctoral Thesis, Departamento de Ingeniería del Terreno, Cartográfica y Geofísica, Universidad Politécnica de Cataluña, Barcelona

Carreño ML, Cardona OD, Barbat AH (2007a) Urban seismic risk evaluation: a holistic approach. Nat Hazards 40(1):137-172

Carreño ML, Cardona OD, Barbat AH (2007b) A disaster risk management performance index. Nat Hazards 41(1):1-20 
CEN (2004) Eurocode 8: design of structures for earthquake resistance part 1: general rules, seismic actions and rules for buildings. Comité Européen de Normalisation, Brussels

Cid J, Susagna T, Goula X, Chavarria L, Figueras S, Fleta J, Casas A, Roca A (2001) Seismic zonation of Barcelona based on numerical simulation of site effects. Pure Appl Geophys 158:2559-2577

Coburn A, Spence R (2002) Earthquake protection, 2nd edn. Wiley \& Sons, Chichester

Corsanego A, Petrini V (1994) Evaluation criteria of seismic vulnerability of the existing building patrimony on the national territory. Seism Eng 1:16-24

Departament d'Estadística (2002) Anuari estadístic de la ciutat de Barcelona 2002. Departament d' Estadística, Ajuntament de Barcelona, Barcelona (in Catalan)

Egozcue JJ, Barbat A, Canas JA, Miquel J, Banda E (1991) A method to estimate intensity occurrence probabilities in low seismic activity regions. Earthq Eng Struct Dyn 20:43-60

Fajfar P (2002) Structural analysis in earthquake engineering - a breakthrough of simplified non-linear methods. Proceedings of the 12th European conference on earthquake engineering, London

Fajfar P, Gaspersic P (1996) The N2 method for the seismic damage analysis of RC buildings. Earthq Eng Struct Dyn 25:23-67

FEMA/NIBS (2002) Earthquake loss estimation methodology, HAZUS-99 service release 2 (SR2) technical manual. National Institute of Building Sciences for the Federal Emergency Management Agency, Washington, DC

Giovinazzi S, Lagomarsino S (2002) WP04: guidelines for the implementation of the I level methodology for the vulnerability assessment of current buildings, Risk UE report. Genoa (Italy)

GNDT (1994) Scheda di esposizione e vulnerabilità e di rilevamento danni di primo livello e secondo livello (muratura e cemento armato). Gruppo Nazionale per la Difesa dai Terremoti, Roma (in Italian)

Grünthal G (1998) European macroseismic scale 1998. Centre Européen de Géodynamique et de Séismologie, Luxemburg

IMI (2002) Informació del Centre de Cartografia Automàtica (InfoCCA). Institut Municipal d'Informàtica, Ajuntament de Barcelona, Barcelona (in Catalan)

Irizarry J (2004) An advanced approach to seismic risk assessment. application to the cultural heritage and the urban system Barcelona. Doctoral Thesis, Departamento de Ingeniería del Terreno, Cartográfica y Geofísica, Universidad Politécnica de Cataluña, Barcelona

Lantada N (2007) Evaluación del riesgo sísmico mediante métodos avanzados y técnicas GIS. Aplicación a la ciudad de Barcelona. Doctoral Thesis, Departamento de Ingeniería del Terreno, Cartográfica y Geofísica, Universidad Politécnica de Cataluña, Barcelona

Lungu D, Aldea A, Arion A, Vacareanu R, Petrescu F, Cornea T (2001) WP1 report European distinctive features, inventory database and typology. RISK-UE project of the EC: an advanced approach to earthquake risk scenarios with applications to different European towns

Milutinovic ZV, Trendafiloski GS (2003) WP04. vulnerability of current buildings. RISK-UE project of the EC: an advanced approach to earthquake risk scenarios with applications to different European towns

Moreno R, Bairán JM, Pujades LG, Aparicio AC, Barbat AH (2004) Evaluación probabilista del comportamiento sísmicode edificios porticados de hormigón armado. Hormigón Y Acero 231:125-136

Moreno R (2006) Análisis no lineal estático y dinámico para la evaluación del riesgo sísmico en edificios: aplicación a diversos escenarios sísmicos de Barcelona. Doctoral Thesis, Departamento de Ingeniería del Terreno, Cartográfica y Geofísica, Universidad Politécnica de Cataluña, Barcelona

MV101 (1963) Norma N.V.101-1962. Acciones en la edificación. Ministerio de la Vivienda, decreto del 17 de enero de $1963(195 / 1963)$

NCSE-94 (1994) Norma de Construcción Sismorresistente Española, Parte General y de Edificación. Comisión Permanente de Normas Sismorresistentes, Real Decreto 2543/1994 del 29 de diciembre de 1994, Boletín Oficial del Estado no 33, miércoles 8 de febrero de 1995

Olivera C, Redondo E, Lambert J, Riera A, Roca A (2006) Els terratrèmols dels segles XIV i XV a Catalunya. Institut Cartogràfic de Catalunya, Barcelona (in Catalan)

PDS-1 (1974) Norma Sismorresistente P.D.S.-1. Comisión Interministerial de la Presidencia del Gobierno, Decreto de 30 de agosto de 1974, BOE, 279, 21 de noviembre de 1974

PGS-1 (1968) Decreto 106/1968, de 16 de enero, por el que se aprueba la aplicación de la «Norma Sismorresistente PGS 1 (1968), parte A». Presidencia del Gobierno. BOE 30/1968. Fecha de publicación 04/02/1968

Secanell R, Goula X, Susagna T, Fleta J, Roca A (2004) Seismic hazard zonation of Catalonia, Spain integrating uncertainties. J Seismol 8(1):24-40

SISMICAT (2003) Pla especial d'emergències sísmiques a Catalunya (http://www.gencat.net/interior/esc/ docs/esc_sismicat.pdf) (in Catalan)

Unwin D (1981) Introductory spatial analysis. Methuen, London 
Vacareanu R, Lungu D, Aldea A, Arion C (2004) WP7 report seismic risk scenarios handbook. RISK-UE project of the EC: an advanced approach to earthquake risk scenarios with applications to different European towns

Whitman RW (1973) Damage probability matrices for prototype buildings. Massachusetts Institute of Technology, Department of Civil Engineering Research. Report R73-57, Cambridge, MA 